
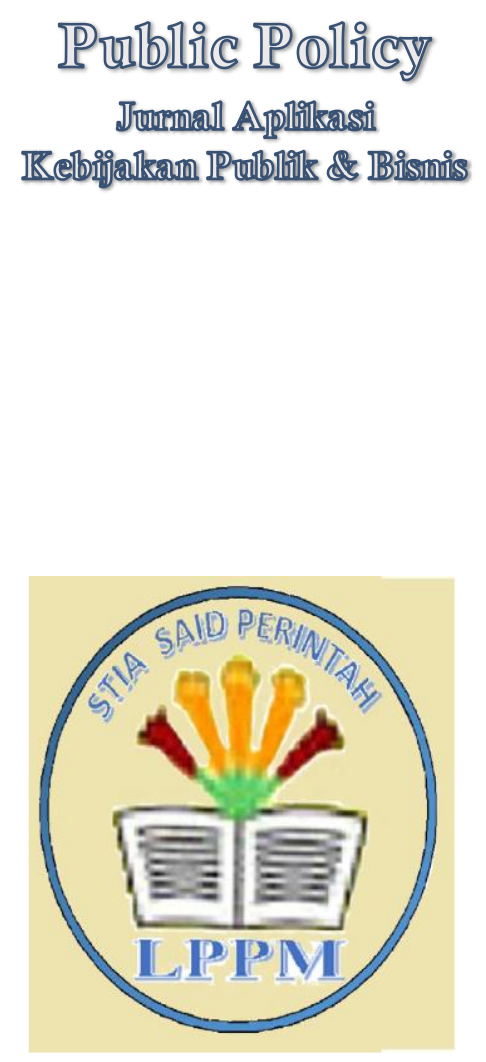

LPPM STIA Said Perintah

Volume 2, No. 1, Maret 2021

https://stia-saidperintah.e-journal.id/ppj

\section{Dampak Insentif, Desentraliasi dan \\ Sistim Pengendalian Internal Terhadap Kinerja Pegawai}

\section{Gilbert Alvin Rumalatu' \\ Anthoneta Telsy Waelauruw ${ }^{2}$ \\ (Penulis Korespendesi)}

\author{
1,2Jurusan Adm. Niaga Politeknik Negeri Ambon \\ telsysaiya@gmail.com
}

\begin{abstract}
This study aims to test and analyze impact of incentive, decentralization effect and intern government control system to employee performance in Dinas Parivisata, Pemuda dan Olah Raga Kabupaten Maluku Tengah. Population from the research is from all employees In Dinas Pariwisata, Pemuda dan Olah Raga Kabupaten Maluku Tengah. It takes 46 respondent from the government employees and salaries employees. Data collection is done with a direct survey with census method as a sample gathering method. Hypothesis testing empirically using a Multiple Liniear Regression.

The research result shows that incentive is proven positive and significant effect employee performance. This mean if the incentive is raise or getting better have a good effect to employee performances. Decentralization is proven positive and significant to employee performance and this mean that authority delegation and the responsible are not did not go well on employee performance. Further intern control is proven positive and significant effect to employee performance. Which it's mean if the government control system runs well then it will effect indirectly to employee performance goes better.
\end{abstract}

Keywords : Incentive, Decentralization, Government Internal Control System, Performance 


\section{Pendahuluan}

Kinerja pegawai, khususnya Pegawai Negeri Sipil (PNS) saat ini sedang menjadi sorotan publik, dikarenakan kinerja pegawai negeri dalam melaksanakan tugas dan kewajibannya. Salah satu penyebabnya adalah karena panjangnya sistem birokrasi dalam organisasi kepegawaian negeri, hal ini merupakan dampak sistim pemerintahan sentralistik dari zaman orde lama sehingga olehnya diperlukan solusi melalui adanya reformasi dalam penyelenggaraan negara termasuk pemerintahannya (Eduard Yohannis Tamaela, et.all., 2020) yang dapat dilakukan melalui sistim desentralisasi. Menurut Undang-Undang No. 24 Tahun 2014, (2014), desentralisasi adalah penyerahan urusan pemerintahan oleh pemerintah pusat kepada daerah otonom berdasarkan asas otonomi. Pendapat lain oleh Luthans, (2002) dalam konteks yang lebih sempit mengatakan bahwa desentralisasi merupakan pelimpahan wewenang atau tanggung jawab dalam pelaksanaan tugas mengakibatkan manajer yang berada dibawahnya akan berpartisipasi dalam pengambilan keputusan disamping akan terjadi pemberdayaan sumber daya manusia (bawahannya), sehingga akan meningkatkan motivasi manajer dalam melaksanakan kegiatannya yang pada akhirnya secara signifikan akan memiliki pengaruh positif terhadap peningkatan kinerjanya.

Salah satu faktor utama yang berpotensi mempengaruhi kinerja pegawai adalah rendahnya tingkat kesejahteraan PNS sehingga melahirkan sistim remunerasi yang diharapkan dapat meningkatkan kinerja sekaligus memperbaiki tingkat kesejahteraan PNS dan menghindari adanya praktek-praktek kerja yang tidak terpuji oleh apparat pemerintah (Nahuway \& Tamaela, 2020). Dalam mekanisme kerja suatu organisasi, khususnya pada organisasi yang banyak melibatkan tenaga manusia, maka prinsip yang perlu dikembangkan adalah take and give, yang artinya bahwa organisasi tersebut disamping bersedia memenuhi kebutuhan para pegawai juga menuntut adanya seorang pemimpin yang dapat memperlakukan bawahan dengan baik (Rusilawati, 2014) yang dengan demikian para pegawai akan dengan sukarela untuk mengorbankan dirinya demi kepentingan organisasi.

Pernyataan ini sejalan dengan pernyataan Rusilawati, (2014) yang menyatakan bahwa insentif merupakan salah satu determinan kinerja pegawai dalam bentuk uang sebagai penghargaan terhadap kinerja yang berkontribusi kepada organisasi (Mangkuprawira, S., 2007). Artinya bahwa semakin besar perhatian perusahaan 
terhadap kebutuhan karyawannya maka perusahaan tersebut akan mendapat timbal balik (take and give) yang sesuai, yaitu maksimalisasi dalam kinerja.

Aspek lain yang juga berpotensi mempengaruhi kinerja PNS adalah sistem pengendalian internal pemerintah. Hal ini pernah disampaikan oleh Sarita Permata Dewi, (2012) yang mengadopsi teori Dale Timple bahwa salah satu factor yang mempengaruhi kinerja pegawai adalah factor eksternal diantaranya adalah lingkungan, kebj̈akan dan pengawasan yang merupakan bentuk dari pengendalian internal dan memiliki pengaruh terhadap kinerja pegawai. Hal ini juga pernah disampaikan oleh Anthony \& Govindarajan, (2005) dalam Agripa Fernando Tarigan, (2011) yang menyatakan bahwa suatu sistem merupakan suatu cara tertentu dan bersifat repetitif untuk melaksanakan suatu atau sekelompok aktivitas. Sistem pengendalian internal yang baik berpengaruh pada cara manapun tujuannya; artinya tindakan-tindakan individu untuk meraih tujuan-tujuan pribadinya juga akan membantu dalam pencapaian tujuan-tujuan organisasi (Anthony \& Govindarajan, 2002 dalam Tarigan, 2011).

Determinan kinerja pegawai diatas telah banyak diteliti dan menunjukan hasil penelitian yang beragam dan menunjukan bahwa ada ambivalesi hasil-hasil penelitian terdahulu. Hal ini terlihat pada hasil kajian oleh Tarigan, (2011); Indudewi \& Nafasati, (2012) yang menyatakan bahwa insentif dan desentralisasi tidak berhubungan dan juga tidak mempengaruhi kinerja pegawai. Hasil ini juga diakui oleh Supriyanto, (2014) bahwa insentif yang dalam kajiannya diwakili oleh sistim remunerasi secara parsial tidak berpengaruh terhadap kinerja pegawai. Hasil kajian terdahulu diatas ternyata tertentangan dengan hasil kajian oleh Karyanti, (2010) dan Jusuf, (2013) menyatkan bahwa insentif mapun penghargaan lainnnya berpengaruh secara signifikan terhadap kinerja serta hasil kajian oleh Mazura, (2011) mengatakan bahwa insentif berpengaruh positif dan signifikan terhadap kinerja PNS.

Hasil penelitian terdahulu yang menunjukan adanya ambivalensi kontradiksi hasil penelitian tersebut sebenarnya adalah research gap (kesenjangan penelitian) yang oleh Ferdinand, (2006) disebutkan bahwa research gap tersebut dapat atau seharusnya dikembangkan sebagai masalah penelitian. Berdasarkan pertimbangan inilah maka penulis memutuskan untuk melakukan penelitian secara lebih mendalam dengan tujuan untuk menganalisis dampak insentif, desentralisasi dan sistem pengendalian internal terhadap kinerja pegawai. 


\section{Kerangka Teoritis dan Pengembangan Hipotesa Penelitian Insentif}

Sarwoto, (1997) mengatakan bahwa insentif sebagai sarana motivasi dapat diberi batasan perangsang atau pendorong yang diberikan dengan sengaja kepada para pekerja agar dalam diri mereka timbul semangat yang lebih besar untuk berprestasi bagi organisasi. Pengertian lain oleh Dessler, (2003) mengemukakan pendapatnya mengenai insentif finansial adalah ganjaran finansial yang diberikan kepada karyawan yang tingkat produksinya melampaui standar yang sudah ditetapkan sebelumnya. Didalam penerapan suatu sistem insentif dalam organisasi yang menginginkan pamrih dari pekerjaanya, tidak semua bentuk insentif yang diberikan kepada pegawai dapat memberi pengaruh langsung terhadap semangat kerja pegawai.

\section{Desentralisasi}

Otonomi daerah di Indonesia merupakan salah satu bentuk desentralisasi dimana pemerintah pusat memberikan sebagian kewenangannya kepada pemerintah daerah untuk mengelola daerahnya. Pelimpahan wewenang tentunya disertai dengan pelimpahan tanggung jawab sehingga tiap-tiap satuan kerja wajib mempertanggungjawabkan anggaran dan pencapaian realisasi dari target yang telah ditetapkan. Dengan adanya desentralisasi, tiap-tiap satuan kerja dapat meningkatkan kinerjanya karena mereka mengetahui kondisi masyarakat dan dapat menetapkan program-program yang tepat sasaran (Chenhall; Mukhi et al., Davis dan Newstrom dalam Miah, (1996). Gordon dan Miller (1976) dalam Karyanti, (2010) berpendapat bahwa desentralisasi pengambilan keputusan diantara manajer bertujuan meningkatkan kinerja mereka dengan mendorong mereka untuk mengembangkan kemampuan khas mereka untuk menangani kondisi-kondisi local yang tidak menentu. Mukhi et al., dalam Miah, (1996) menyatakan bahwa desentralisasi memungkinkan para manajer secara efektif menangani peristiwa-peristiwa, bertindak tanpa menunggu dan meningkatkan kualitas keputusan yang mendorong ke kinerja yang lebih baik. Selain pelimpahan wewenang, desentralisasi dapat pula berupa kemandirian dalam mengelola sumber daya di daerah.

\section{Sistem Pengendalian Internal}

Menurut Peraturan Pemerintah No. 60 Tahun 2008, sistem pengendalian intern adalah proses yang integral pada tindakan dan kegiatan yang dilakukan secara terus menerus oleh pimpinan dan seluruh pegawai untuk memberikan keyakinan memadai 
atas tercapainya tujuan organisasi melalui kegiatan yang efektif dan efisien, keandalan pelaporan keuangan, pengamanan aset negara, dan ketaatan terhadap peraturan perundang-undangan. Tujuan adanya pengendalian intern: (1) Menjaga kekayaan organisasi/mengamankan asset, (2) Memeriksa ketelitian dan kebenaran data akuntansi, (3) Mendorong efisiensi, (4) Mendorong dipatuhinya kebïakan manajemen.

\section{Kinerja}

Kinerja merupakan adalah catatan mengenai akibat-akibat yang dihasilkan pada sebuah fungsi kerja atau kegiatan tertentu dalam suatu jangka waktu tertentu Bernardin, H. J., \& Russel A. E. J., (1988). Pendapat lain oleh Motowidlo dan Van Scotter, (1994) dalam Tarigan, (2011) kinerja kerja mengacu pada hasil- hasil yang diperoleh dari tugastugas yang substantif yang membedakan pekerjaan seseorang dengan pekerjaan yang lainnya serta meliputi aspek-aspek yang lebih teknis mengenai kinerja. Berdasarkan uraian-uraian diatas, secara umum disimpulkan bahwa kinerja kerja adalah kegiatan yang menghasilkan suatu akibat, pelaksanaan suatu tindakan atau serangkaian tindakan penyelesaian suatu pekerjaan untuk mencapai tujuan-tujuan organisasi.

\section{Penelitian Terdahulu dan Pengembangan Hipotesa Penelitian}

Kajian-kajian emipiris yang mendasari model konseptual penelitian (insentif, desentralisasi, sistim pengendalian internal dan kinerja) akan dipaparkan dibawah ini. Kajian menyangkut insentif oleh Mazura, (2011) mengatakan bahwa insentif berpengaruh positif dan signifikan terhadap kinerja PNS Badan Kepegawaian Daerah Kabupaten Bengkalis. Penelitian lainnya oleh Jusuf, (2013) menyatkan bahwa Secara parsial, TQM dan reward berpengaruh secara signifikan terhadap kinerja manajerial, sedangkan sistem pengukuran kinerja tidak berpengaruh secara signifikan terhadap kinerja manajerial dan secara simultan, TQM, sistem pengukuran kinerja dan reward berpengaruh terhadap kinerja manajerial pada PT. Cahaya Murni Raya Industri.

Hasil kajian lain oleh Tarigan, (2011) menunjukan bahwa; tujuan yang jelas dan terukur, insentif, motivasi kerja, remunerasi, desentralisasi tidak berhubungan dengan kinerja pegawai. Hasil diatas didukung oleh Indudewi \& Nafasati, (2012) yang menyatakan bahwa insentif dan desentralisasi tidak berpengaruh terhadap kinerja Fakultas di Universitas Semarang yang berpengaruh adalah ukuran kinerja dan kejelasan sasaran. Sejalan dengan hasil kedua penelitian diatas, Indudewi pada tahun 2011 juga menunjukan bahwa sasaran yang jelas dan terukur, insentif dan pengukuran kinerja berpengaruh positif dan signifikan terhadap kinerja SKPD dan BUMD di Kota Semarang. 
Ia menambahkan bahwa desentralisasi memiliki hubungan positif tapi tidak berpengaruh terhadap kinerja SKPD dan BUMD di Kota Semarang. Kajian lainnya oleh Supriyanto, (2014) juga mendukung hasil diatas bahwa penetapan sasaran berpengaruh secara parsial terhadap kinerja pegawai namun tidak pada insentif yang dalam kajiannya diwakili oleh variabel sistim remunerasi yang ternyata secara parsial tidak berpengaruh terhadap kinerja pegawai.

Hasil kajian emipiris selanjutnya menyangkut sistim pengendalian internal disampaikan oleh Linda Oktarnia, (2013) yang mengungkapkan bahwa lingkungan pengendalian, penaksiran resiko dan pemantauan ternyata tidak berpengaruh signifikan terhadap kinerja karyawan keuangan Rumah Sakit Tanjungpinang dan Bintan, yang berpengaruh hanyalah aktifitas pengendalian internal. Selanjutnya hasil kajian juga menemukan lingkungan pengendalian, aktivitas pengendalian, penaksiran risiko, informasi dan komunikasi, dan pemantauan secara simultan berpengaruh signifikan terhadap kinerja karyawan.

Hasil kajian lain oleh Sarita Permata Dewi, (2012) menunjukan bahwa; faktor internal adalah faktor-faktor yang berhubungan dengan sifat-sifat seseorang meliputi sikap, siffat kepribadian, sifat fisik, motivasi, umur, jenis kelamin, pendidikan, pengalaman kinerja, latar belakang budaya dan variabel personal lainnya. Sedangkan faktor eskternal adalah faktor-faktor yang mempengaruhi kinerja karyawan yang berasal dari lingkungan meliputi kebïakan organisasi, kepemimpinan, tindakan-tindakan rekan kerja, pengawasan, system upah, dan lingkungan.

Konsep dan hasil kajian-kajian empiris diatas selanjutnya melahirkan kerangka konseptual kajian ini seperti yang terlihat pada gambar berikut ini.

\section{Kerangka Konseptual}

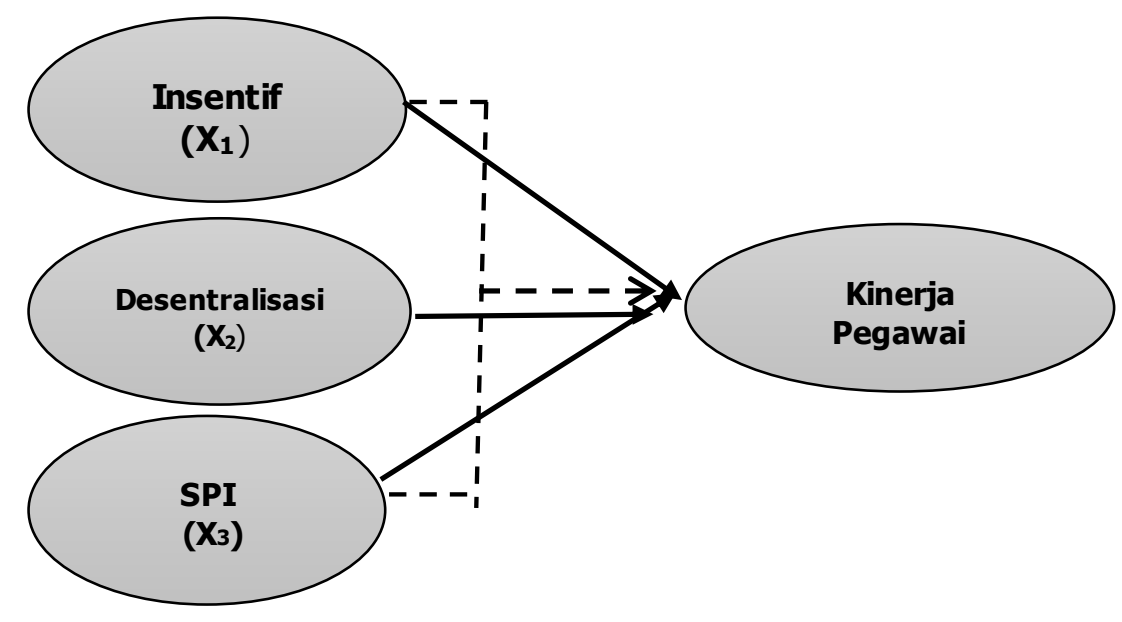


Berdasarkan pemaparan konsep, hasil penelitian terdahulu serta kerangka konseptual diatas maka hipotesis penelitian yang diajukan untuk diuji selanjutnya antara lain;

Hipotesis 1 ; Insentif berpengaruh positif terhadap kinerja pegawai.

Hipotesis 2 ; Desentralisasi berpengaruh positif terhadap kinerja pegawai.

Hipotesis 3 ; Sistem pengendalian internal pemerintah berpengaruh positif terhadap kinerja pegawai.

Hipotesis 4 ; Insentif, desentralisasi dan sistem pengendalian internal secara simultan berpengaruh positif terhadap kinerja.

\section{Metode Penelitian}

Jenis penelitian ini merupakan penelitian penjelasan (eksplanatory) dengan tujuan untuk menjelaskan dampak pengaruh insentif, desentralisasi dan sistem pengendalian internal pemerintah terhadap kinerja pegawai. Model penelitian yang digunakan adalah survei dengan bantuan instrument kuesioner untuk pengumpulan data penelitian. Populasi dalam kajian ini adalah seluruh pegawai Dinas Pariwisata, Pemuda dan Olah Raga Kabupaten Maluku Tengah dan penarikan sampelnya menggunakan teknik sensus sehingga seluruh pegawai Dinas Parivisata, Pemuda dan Olah Raga Kabupaten Maluku Tengah dijadikan sebagai sampel penelitian yakni sebanyak 48 pegawai. Kuesioner penelitian dibagiakan untuk seluruh sampel penelitian dan yang kembaii hanyalah 46 kuesioner sehingga sampel akhir adalah sebanyak 46 pegawai. Alat analisis yang digunakan untuk menjawab masalah penelitian adalah analisis regresi linier berganda dengan persamaan sebagai berikut;

$Y=a+\beta_{1} X_{1}+\beta_{2} X_{2}+\beta_{3} X_{3}+\varepsilon$

Keterangan;

$Y=$ Kinerja pegawai

$\mathrm{a}=$ Intercept

$\beta=$ Koefisien regresi

$X_{1}=$ Insentif

$\mathrm{X}_{2}=$ Desentralisasi

$\mathrm{X}_{3}=$ Sistim pengendalian internal

$\varepsilon=$ Residual 
Uji hipotesis dalam penelitian ini menggunakan uji t dengan tingkat signifikansinya sebesar $5 \%$ dengan kriteria pengujiannya adalah; jika $\mathrm{t}$ hitung $>\mathrm{t}$ tabel maka $\mathrm{HO}$ ditolak dan Ha diterima.

\section{Pembahasan Hasil Penelitian}

\section{Uji Kualitas Instrumen Penelitian}

Pengujian validitas dalam kajian ini mengunakan korelasi Product Moment Person, dimana valid atau tidaknya instrumen dapat diketahui dengan membandingkan indeks korelasi Product Moment Person dengan signifikan 5\% (Ferdinand, 2006). Pengujian selanjutnya adalah Pengujian reliabilitas kajian ini menggunakan alpha cronbachs dimana suatu instrumen dapat dikatakan reliabel jika memiliki nilai koefisien keandalan lebih besar atau sama dengan 0.6 artinya apabila $a=0.6$ maka instrumen dapat dikatakan reliabel (Ferdinand, 2006). 
Uji Validitas \& Reliabilitas

\begin{tabular}{|c|c|c|c|c|c|c|c|}
\hline \multirow[b]{2}{*}{ Variabel } & \multirow[b]{2}{*}{ Indikator } & \multicolumn{4}{|c|}{ Uji Validitas } & \multicolumn{2}{|c|}{ Uji Reliabilitas } \\
\hline & & Item & $\mathbf{R}$ & sig & Ket & $\begin{array}{c}\text { Koefisien } \\
\text { Alpha }\end{array}$ & Ket \\
\hline \multirow{5}{*}{$\begin{array}{l}\text { Insentif } \\
\left(\mathrm{X}_{1}\right)\end{array}$} & \multirow{3}{*}{ Penilaian disiplin } & $\mathrm{X}_{1.1}$ & 0.600 & 0.000 & Valid & \multirow{5}{*}{0.600} & \multirow{5}{*}{ Reliabel } \\
\hline & & $X_{1.2}$ & 0.629 & 0.000 & Valid & & \\
\hline & & $\mathrm{X}_{1.4}$ & 0.548 & 0.000 & Valid & & \\
\hline & \multirow{2}{*}{$\begin{array}{l}\text { Penilaian hasil } \\
\text { kinerja }\end{array}$} & $X_{1.5}$ & 0.744 & 0.000 & Valid & & \\
\hline & & $X_{1.6}$ & 0.579 & 0.000 & Valid & & \\
\hline \multirow{5}{*}{$\begin{array}{l}\text { Desntralisasi } \\
\left(\mathrm{X}_{2}\right)\end{array}$} & Keuangan & $\mathrm{X}_{2.1}$ & 0.666 & 0.000 & Valid & \multirow{5}{*}{0.629} & \multirow{5}{*}{ Reliabel } \\
\hline & Operasional & $X_{2.2}$ & 0.761 & 0.000 & Valid & & \\
\hline & Mutu pegawai & $X_{2.3}$ & 0.763 & 0.000 & Valid & & \\
\hline & Alokasi rekening & $X_{2.4}$ & 0.742 & 0.000 & Valid & & \\
\hline & Perputaran pegawai & $X_{2.5}$ & 0.586 & 0.000 & Valid & & \\
\hline \multirow{6}{*}{$\begin{array}{c}\text { Sistim } \\
\text { Pengendalian } \\
\text { Intern } \\
\left(\mathrm{X}_{3}\right)\end{array}$} & \multirow{3}{*}{$\begin{array}{l}\text { Lingkungan } \\
\text { pengendalian }\end{array}$} & $X_{3.1}$ & 0.851 & 0.000 & Valid & \multirow{6}{*}{0.548} & \multirow{6}{*}{ Reliabel } \\
\hline & & $X_{3.2}$ & 0.860 & 0.000 & Valid & & \\
\hline & & $X_{3.3}$ & 0.757 & 0.000 & Valid & & \\
\hline & \multirow{3}{*}{ Penilaian resiko } & $X_{3.4}$ & 0.714 & 0.000 & Valid & & \\
\hline & & $X_{3.5}$ & 0.578 & 0.000 & Valid & & \\
\hline & & $X_{3.6}$ & 0.602 & 0.000 & Valid & & \\
\hline \multirow{12}{*}{ Kinerja $(Y)$} & \multirow{4}{*}{$\begin{array}{l}\text { Keahlian } \\
\text { teknikal inti }\end{array}$} & $Y_{1.1}$ & 0.568 & 0.000 & Valid & \multirow{12}{*}{0.744} & \multirow{12}{*}{ Reliabel } \\
\hline & & $Y_{1.2}$ & 0.440 & 0.000 & Valid & & \\
\hline & & $Y_{1.3}$ & 0.631 & 0.000 & Valid & & \\
\hline & & $Y_{1.4}$ & 0.721 & 0.000 & Valid & & \\
\hline & \multirow{4}{*}{ Dedikasi kerja } & $Y_{1.5}$ & 0.661 & 0.000 & Valid & & \\
\hline & & $Y_{1.6}$ & 0.697 & 0.000 & Valid & & \\
\hline & & $Y_{1.7}$ & 0.691 & 0.000 & Valid & & \\
\hline & & $Y_{1.8}$ & 0.634 & 0.000 & Valid & & \\
\hline & \multirow{4}{*}{$\begin{array}{c}\text { Fasilitas } \\
\text { interpersonal }\end{array}$} & $Y_{1.9}$ & 0.642 & 0.000 & Valid & & \\
\hline & & $\mathrm{Y}_{1.10}$ & 0.746 & 0.000 & Valid & & \\
\hline & & $Y_{1.11}$ & 0.571 & 0.000 & Valid & & \\
\hline & & $Y_{111}$ & 0.672 & 0.000 & Valid & & \\
\hline
\end{tabular}

Hasil dari pengujian validitas diatas menunjukan bahwa secara keseluruhan variabel penelitian ini dapat dikatakan valid karena tingkat signifikannya lebih kecil dari 0.05 . Selanjutnya hasil pengujian reliabilitas menunjukan bahwa seluruh variabel terteliti dalam kajian ini ternyata memiliki koefisien korelasi diatas 0.60 sehingga seluruh data penelitian ini dapat dikatakan realibel yang artinya data ini layak untuk dilanjutkan pada pengolahan data pada tahapan selanjutnya.

\section{Uji Asumsi Klasik}

Pengujian normal tidaknya dostribusi data penelitian ini dilakukan dengan melihat peneyebaran data pada normal probability plot. Berdasarkan normal probability plot diatas, maka data penelitian ini dapat dikatakan telah memenuhi kaidah normalitas karena terlihat bahwa data menyebar mengikuti garis diagonal, penyebarannya secara acak dan tidak membentuk pola tertentu. Pengujian heteroskedastisitas dalam penelitian 
ini dilakukan dengan melihat gambar charts scatterplot. Hasil uji menunjukan bahwa data penelitian bebas heterokedastisitas karena titik-titik data menyebar diatas dan dibawah angka 0 pada sumbu $Y$. Pengujian multikolinearitas kajian ini menggunakan melihat nilai Variance Inflation Faktor(VIF) atau faktor pertambahan ragam. Apabila nilai VIF lebih besar dari 10 maka terjadi multikolinieritas, sebaliknya apabila VIF lebih kecil dari 10 maka tidak terjadi multikolinieritas. Hasil uji menunjukan bahwa nilai tolerance mendekati 1 dan nilai VIF berada dibawah 10 yang berarti tidak terjadi multikolinearita s antar variabel independen dalam penelitian ini.

\section{Uji Regresi Linier Berganda}

Dalam penelitian ini analisis regresi linier berganda digunakan oleh peneliti untuk mengetahui pengaruh insentif, desentralisasi dan sistem pengendalian internal pemerintah terhadap kinerja pegawai. Berikut ini hasil analisis yang terlihat dibawah ini.

\section{Analisis Regresi Linier Berganda}

\begin{tabular}{|c|c|c|c|c|}
\hline Variabel & Coefficients & $\begin{array}{c}\mathbf{t} \\
\text { hitung }\end{array}$ & Sig & Keterangan \\
\hline Constant & 2.074 & \multicolumn{3}{|l|}{} \\
\hline Insentif & 1.530 & 5.697 & 0.000 & signifikan \\
\hline Desentralisasi & 0.459 & 1.952 & 0.580 & tidak signifikan \\
\hline SPI & 0.596 & 2.292 & 0.023 & signifikan \\
\hline Adjusted R Square & 0.745 & 0.000 & signifikan \\
\hline F & 44.868 & \\
\hline F tabel & 2.84 & & \\
\hline t tabel & 2.012 &
\end{tabular}

Data diatas menunjukan nilai konstanta sebesar 2.074 mengartikan mengartikan bahwa jika tidak ada kenaikan nilai dari insentif, desentralisasi dan sistim pengendalian intern (SPI) maka besarnya adalah nilai variabel kinerja adalah sebesar 2.074. Koefisien insentif sebesar 1.530 menunjukkan bahwa setiap nilai insentif meningkat atau semakin baik maka nilai kinerja akan meningkat sebesar nilai koefisien regresi insentif atau dengan kata lain setiap peningkatan kinerja dibutuhkan nilai insentif sebesar 1.530 dengan asumsi besarnya nilai desentralisasi dan SPI adalah tetap.

Koefisien regresi desentralisasi sebesar 0.459 menunjukkan bahwa setiap nilai desentralisasi meningkat atau semakin baik maka nilai kinerja akan meningkat sebesar nilai koefisien regresi desentralisasi atau dengan kata lain setiap peningkatan kinerja dibutuhkan nilai desentralisasi sebesar 0.459 dengan asumsi besarnya nilai insentif dan SPI adalah tetap atau konstant. Koefisien regresi terakhir yakni SPI sebesar 0.596 
menunjukkan bahwa setiap nilai SPI meningkat atau semakin baik maka nilai kinerja akan meningkat sebesar nilai koefisien regresi SPI atau dengan kata lain setiap peningkatan kinerja dibutuhkan nilai SPI sebesar 0.596 dengan asumsi besarnya nilai insentif dan desentralisasi adalah tidak berubah.

Data diatas juga menunjukan bahwa model konseptual penelitian yang dibangun adalah layak karena terbukti bahwa kinerja pegawai mampu dj̈elaskan dengan baik oleh insentif, desentralisasi dan SPI dengan nilai determinasi atau tingkat kelayakan sebesar 0.745 atau sebesar $74.5 \%$ sementara $25.5 \%$ lainnya dj̈elaskan oleh variabel lain diluar model penelitian.

\section{Pengujian Hipotesis Penelitian}

Hasil pengujian hipótesis pertama mengungkapkan bahwa insentif memiliki nilai $t_{\text {hitung }}$ sebesar 5.697 yang lebih besar dari nilai $t_{\text {tabel }}$ yaitu $2.012(5.697>2.012)$ yang berarti bahwa terima $\mathrm{Ha}$ dan tolak $\mathrm{HO}$ atau hipotesis pertama diterima. Hasil ini menunjukan bahwa insentif berpengaruh positif dan signifikan terhadap kinerja pegawai Dinas Pariwisata, Pemuda dan Olah Raga Kabupaten Maluku Tengah. Hasil pengujian hipótesis kedua mengungkapkan bahwa desentralisasi memiliki nilai $t_{\text {hitung }}$ sebesar 1.952 yang lebih kecil dari nilai tabel yaitu $2.012(1.952<2.012)$ yang berarti bahwa tolak $\mathrm{Ha}$ dan terima $\mathrm{HO}$ atau hipotesis kedua ditolak. Hasil ini menunjukan bahwa desentralisasi berpengaruh positif tetapi tidak signifikan terhadap kinerja pegawai Dinas Parivisata, Pemuda dan Olah Raga Kabupaten Maluku Tengah.

Hasil pengujian hipótesis ketiga mengungkapkan bahwa SPI memiliki nilai $t_{\text {hitung }}$ sebesar 2.292 yang lebih besar dari nilai ttabel yaitu 2.012 (2. $292>2.012$ ) yang berarti bahwa terima $\mathrm{Ha}$ dan tolak $\mathrm{HO}$ atau hipotesis ketiga diterima. Hasil ini menunjukan bahwa SPI berpengaruh positif dan signifikan terhadap kinerja pegawai Dinas Parivisata, Pemuda dan Olah Raga Kabupaten Maluku Tengah. Hasil pengujian hipótesis keempat mengungkapkan bahwa insentif, desentralisasi dan SPI yang memiliki nilai $t_{\text {hitung }}$ sebesar 44.868 yang lebih besar dari nilai tabel yaitu 2.84 (44.868 > 2.84) yang berarti bahwa terima $\mathrm{Ha}$ dan tolak $\mathrm{HO}$ atau hipotesis keempat diterima. Hasil ini menunjukan bahwa insentif, desentralisasi dan SPI secara simultan berpengaruh positif dan signifikan terhadap kinerja pegawai Dinas Pariwisata, Pemuda dan Olah Raga Kabupaten Maluku Tengah. 


\section{Pembahasan Hasil Analisis}

Secara keseluruhan hasil analisis menunjukan bahwa model konseptual yang dibangun telah mampu menjelaskan determinan kinerja pegawai Dinas Pariwisata, Pemuda dan Olah Raga Kabupaten Maluku Tengah dilihat dari insentif, desentralisasi dan sistim pengendalian intern (SPI). Secara detailnya, hasil analisis menunjukan bahwa kinerja pegawai mampu dipengaruhi secara positif dan signifikan oleh intentif dan SPI. Sementara desentralisasi meski berpengaruh namun secara statistik tidak signifikan terhadap perubahan kinerja pegawai. Hasil lainnya juga menunjukan bahwa seluruh prediktor (insentif, desentralisasi dan SPI) secara simultan berpengaruh positif dan signifikan terhadap kinerja pegawai Dinas Pariwisata, Pemuda dan Olah Raga Kabupaten Maluku Tengah.

Insentif dalam kajian ini djelaskan oleh 2 indikator yakni penilaian disiplin dan penilaian hasil kinerja yang selanjutnnya terjabarkan dalam 6 item pernyataan. Seperti yang disentil diatas bahwa inseni karena berpotensi akan melahirkan ketidak puasan yang relatif berakibat kurang baik bagi pegawai yang mengalaminya. Pernyataan ini didasarkan atas pendapat Rusilawati, (2014) yang mengungkapkan bahwa tidak semua bentuk insentif yang diberikan kepada pegawai dapat memberi pengaruh langsung terhadap semangat kerja pegawai

Variabel prediktor berikutnya adalah desentralisasi yang dalam kajian ini terwakili oleh indicator keuangan, operasional, peningkatan mutu pegawai, alokasi rekening maupun perputaran pegawai. Hasil analisis data penelitian menunjukan bahwa desentralisasi berpengaruh tetapi tidak signifikan terhadap kinerja pegawai. Hasil ini dapat djelaskan jika melihat frekuensi jawaban responden yang relatif rendah khususnya pada item penyataan yang berkaitan dengan kewenangan dan tanggung jawab untuk membuat keputusan yang berkaitan dengan pergeseran dana yang telah dianggarkan pada suatu rekening untuk dialihkan ke rekening yang lain dan item pernyataan tentang kewenangan dan tanggung jawab untuk pengalokasian sumber daya manusia. Hal ini berarti pendelegasian wewenang dan tanggung jawab relatif belum berjalan dengan baik. Hasil penelitian ini sesuai dengan hasil penelitian yang dilakukan oleh; Indudewi \& Nafasati, (2012) dan Tarigan, (2011) yang menunjukkan bahwa desentralisasi tidak berpengaruh terhadap kinerja pegawai.

Variabel penelitian terakhir adalah sistim pengendalian intern (SPI) yang dalam kajian ini terukur melalui indikator lingkungan pengendalian dan penilaian risiko yang 
kemudian djabarkan dalam 6 item pernyataan. Hasil analisis membuktikan bahwa SPI berpengaruh positif dan signifikan terhadap kinerja pegawai. Hal ini dapat dilihat melalui koefisien regresi yang menunjukan jika SPI meningkat bmaka peningkatannya akan diikuti oleh peningkatan kinerja. Bukti lain yang mendukung temuan ini adalah pada hasil analisis deskritif. Hasil tersebut menunjukan bahwa nilai mean (nilai rata-rata) persepsi tentang SPI adalah sebesar 4.07 yang berarti bahwa pegawai relatif sangat setuju dengan seluruh pernyataan tentang SPI atau secara tidak langsung dapat dikatakan bahwa SPI dipersepsikan mampu mempengaruhi kinerja pegawai. Item pernyataan yang relatif labih baik dalam menjelaskan variabel ini adalah item menyangkut adanya langkah-langkah pencegahan dan minimalisasi potensi kesalahan yang terjadi (nilai rata-ratanya sebesar 4.30). Hal ini berarti bahwa SPI pada Dinas Pariwisata, Pemuda dan Olah Raga Kabupaten Maluku Tengah akan semakin baik jika program atau kebijakan menyangkut langkah-langkah pencegahan dan minimalisasi potensi kesalahan oleh pegawai dilaksanakan dengan baik.

\section{Penutup}

\section{Kesimpulan}

Berdasarkan pembahasan hasil penelitian maka kesimpulan yang dapat disampaikan melalui penelitian ini adalah sebagai berikut;

1. Insentif dan sistim pengendalian internal berpengaruh positif dan signifikan terhadap kinerja pegawai Dinas Pariwisata, Pemuda dan Olah Raga Kabupaten Maluku Tengah. Hal ini dapat dibuktikan melalui koefisien regresi yang menunjukan jika insentif dan sistim pengendalian internal meningkat, maka peningkatan tersebut akan diikuti oleh peningkatan kinerja pegawai. Dengan demikian dapat dikatakan bahwa peningkatan insentif dan sistim pengendalian internal akan meningkatkan kinerja pegawai Dinas Pariwisata, Pemuda dan Olah Raga Kabupaten Maluku Tengah.

2. Desentralisasi berpengaruh positif tetapi tidak signifikan terhadap kinerja pegawai Dinas Parivisata, Pemuda dan Olah Raga Kabupaten Maluku Tengah. Hal ini dapat dibuktikan melalui koefisien regresi yang menunjukan jika desentralisasi meningkat, maka peningkatan tersebut tidak diikuti oleh peningkatan kinerja pegawai. Dengan demikian dapat dikatakan bahwa peningkatan desentralisasi tidak akan 
meningkatkan kinerja pegawai Dinas Pariwisata, Pemuda dan Olah Raga Kabupaten Maluku Tengah.

3. Insentif, desentralisasi dan sistim pengendalian intern secara simultan berpengaruh positif dan signifikan terhadap kinerja pegawai Dinas Parivisata, Pemuda dan Olah Raga Kabupaten Maluku Tengah. Hal ini dapat dibuktikan melalui koefisien regresi yang menunjukan jika Insentif, desentralisasi dan sistim pengendalian intern meningkat, maka peningkatan tersebut akan dilkuti oleh peningkatan kinerja pegawai. Dengan demikian dapat dikatakan bahwa peningkatan Insentif, desentralisasi dan sistim pengendalian intern secara simultan akan meningkatkan kinerja pegawai Dinas Parivisata, Pemuda dan Olah Raga Kabupaten Maluku Tengah.

\section{Saran}

Berdasarkan sumpulan hasil penelitian maka saran yang dapat diberikan melalui hasil kajian ini adalah bahwa hasil analisis menunjukan bahwa variabel prediktor yang memiliki kontribusi pengaruh yang relatif lebih kecil adalah desentraliasi yang berkaitan dengan pelimpahan wewenang dan tanggung jawab ke satuan dibawahnya. Berdasarkan temuan ini maka disarankan kepada pimpinan Dinas Pariwisata, Pemuda dan Olah Raga Kabupaten Maluku Tengah agar lebih memberikan ruang yang lebih besar khususnya menyangkut pelimpahan kewenangan dan tanggung jawab dalam pekerjaan.

\section{Daftar Pustaka}

Agripa Fernando Tarigan. (2011). Analisis Faktor - Faktor yang Mempengaruhi Kinerja Pegawai Dalam Organisasi Sektor Publik (Studi pada Kantor Pelayanan Pajak Pratama Semarang Tengah Satu). Universitas Diponegoro.

Bernardin, H. J., \& Russel A. E. J. (1988). Human Resources Management: An Experimental Approach (2nd ed.). New York: Irwin McGraw-Hill Inc.

Dessler, G. (2003). Human Resources Management (Nith Editi). Florida: International University.

Eduard Yohannis Tamaela, Victor Pattiasina, Margaretha B. Dasinapa, Yohanes Marani, J. A. D. (2020). Regional Financial Monitoring Models With Community Participation And Public Policy Transparency As Moderators. InternationalJournal of Psychosocial Rehabilitation, 24(02), 4223-4232.

https://doi.org/10.37200/IJPR/V24I2/PR200745 
Ferdinand, A. (2006). Metode Penelitian Manajemen; Pedoman Penelitian Untuk Penulisan Skripsi, Tesis Dan Disertasi Ilmu Manajemen (2nd ed.). Semarang: Badan Penerbit Universitas Diponegoro.

Indudewi, D., \& Nafasati, F. (2012). Pengaruh Insentif, Desentralisasi, Ukuran Kinerja dan Kejelasan Sasaran terhadap Kinerja Organisasi (Studi Kasus pada Fakultas Fakultas di Lingkungan Universitas Semarang). Jurnal Dinamika Sosbud, 14(1), 5362.

Jusuf, R. S. (2013). Analisis Pengaruh Tqm, Sistem Pengukuran Kinerja Dan Reward Terhadap Kinerja Manajerial. Jurnal Riset Ekonomi, Manajemen, Bisnis Dan Akuntansi, 1(3), 634-644. https://doi.org/10.35794/emba.v1i3.1870

Karyanti, T. D. (2010). Pengaruh Kejelasan Sasaran, Desentralisasi, Dan Sistem Pengukuran TerhadapKinerja Organisasi Sektor Publik (Studi Empiris Di Politeknik Negeri Semarang). Universitas Diponegoro.

Linda Oktarnia. (2013). Pengaruh Penetapan Sasaran dan Sistem Remunerasi Terhadap

Kinerja Pegawai Organisasi Sektor Publik (Studi pada Kantor Pelayanan Perbendaharaan Negara di JawaTimur). Pene. Retrieved from http://jurnal.umrah.ac.id/archives/3070

Luthans, F. (2002). Organżational Behavior (9th ed.). New York: Mc Graw-Hill Irwin.

Mangkuprawira, S., dan A. V. H. (2007). Manajemen Mutu Sumber Daya Manusia. Bogor: Penerbit Ghalia Indonesia.

Mazura, M. dan R. (2011). Pengaruh Insentif Terhadap Kinerja Pegawai Negeri Sipil (Studi Kasus Pada Badan Kepegawaian Daerah Kabupaten Bengkalis). Politeknik Negeri Bengkalis.

Miah, N. Z. dan L. M. (1996). Decentralization, Accounting Controls and Performance of Government Organizations: a New Zealand Empirical Study. Financial, Accountabilty and Management, 12(3), 173-190. Retrieved from https://uww.researchgate.net/publication/230263649_Decentralization_accountin g_controls_and_performance_of_government_organizations_A_New_Zealand_em pirical_study

Rusilawati, D. dan B. I. (2014). Pemberian Insentif Dalam Memacu Kinerja. E Journal Administrative Reform, 2(1), 1008-1019. Retrieved from http://ejournals.unmul.ac.id/index.php/JParadigma/article/view/315

Sarita Permata Dewi. (2012). Pengaruh Pengendalian Internal dan Gaya Kepemimpinan 
Terhadap Kinerja Karyawan Spbu Yogyakarta (Studi Kasus Pada Spbu Anak Cabang Perusahaan RB.Group). Jurnal Nominal, 1(1).

Sarwoto, B. (1997). Kasus-Kasus Sumber Daya Manusia. Jakarta: Badan Penerbitan IPWI.

Supriyanto. (2014). Pengaruh Beban Kerja, Pengalaman Audit, Tipe Kepribadian dan Skeptisme Profesional Terhadap Kemampuan Auditor Dalam Mendeteksi Kecurangan (UNIVERSITAS MUHAMMADIYAH SURAKARTA; Vol. 2014). Retrieved from

https://repositories. lib.utexas.edu/handle/2152/39127\%0Ahttps://cris. brighton.ac. uk/ws/portalfiles/portal/4755978/Julius+Ojebode\%27s+Thesis.pdf\%0Ausir.salford .ac.uk/29369/1/Angela_Darvillthesis_esubmission.pdf\%0Ahttps://dspace.lboro.ac .uk/dspace-jspui/ha

Undang-Undang No. 24 Tahun 2014. Pertanggungjawaban atas Pelaksanaan Anggaran Pendapatan dan Belanja Negara Tahun Anggaran 2013. , (2014).

Victorio Fernando Nahuway \& Eduard Yohannis Tamaela. (2020). Model Efektifitas dan Efisiensi E-Procurement serta Dampaknya Terhadap Kepuasan Pengguna di Provinsi Maluku. JURNAL MANEKSI, $9(1), 275-282$. Retrieved from http://ejournalpolnam.ac.id/index.php/JurnalManeksi/article/view/327/351 